\title{
ADHESION OF AXOLEMMAL FRAGMENTS TO SCHWANN CELLS: A SIGNAL- AND TARGET-SPECIFIC PROCESS CLOSELY LINKED TO AXOLEMMAL INDUCTION OF SCHWANN CELL MITOSIS ${ }^{1}$
}

\author{
GEN SOBUE ${ }^{2}$ AND DAVID PLEASURE
}

\author{
Department of Neurology, University of Pennsylvania, and the Children's Hospital of Philadelphia, \\ Philadelphia, Pennsylvania 19104
}

Received April 23, 1984; Revised July 30, 1984; Accepted August 1, 1984

\begin{abstract}
Radioiodinated rat CNS axolemmal fragments adhered to cultured rat Schwann cells by a time-, temperature-, and concentration-dependent process independent of extracellular ionized calcium. Adhesion showed target and signal specificity; axolemmal fragments adhered to endoneurial or dermal fibroblasts to a much lesser extent than to Schwann cells, and plasma membrane fragments from skeletal muscle, erythrocytes, or PNS myelin adhered to Schwann cells to a lesser extent than did axolemmal fragments. Brief trypsinization removed 94 to $97 \%$ of bound radinactivity from Schwann cells previously incubated with ${ }^{125}$ I-axolemmal fragments for up to $24 \mathrm{hr}$, indicating that adhesion was largely a surface phenomenon rather than the result of rapid internalization of axolemmal fragments by the Schwann cells. When adhesion was compared to the axolemmal mitogenic response of Schwann cells, the concentration of axolemmal fragments yielding halfmaximal adhesion was the same as the concentration producing half-maximal stimulation of Schwann cell mitosis. Trypsin digestion, homogenization, or heating of axolemmal fragments before application to cultured Schwann cells diminished adhesion and axolemmal fragment-induced stimulation of Schwann cell mitosis in a parallel fashion. Whereas adhesion of axolemmal fragments to the surfaces of the cultured Schwann cells reached completion within $4 \mathrm{hr}$ in this assay system, induction of Schwann cell mitosis by the fragments required contact with Schwann cells for a minimum of 6 to $8 \mathrm{hr}$ and reached a maximum when the axolemmal fragments had adhered to the Schwann cells for $24 \mathrm{hr}$ or more.
\end{abstract}

The rate of mitosis of cultured non-neoplastic Schwann cells prepared from the neonatal rat is low (Raff et al., 1978a, b; Salzer and Bunge, 1980; Salzer et al., 1980a, b; Kreider et al., 1982 ) but is markedly increased by co-cultivation of the Schwann cells with sensory or autonomic neurons (Wood and Bunge, 1975; McCarthy and Partlow, 1976; Hanson and Partlow, 1978; Salzer and Bunge, 1980; Salzer et al., 1980a, b). In such co-cultures, only those Schwann cells close to neuronal processes are stimulated to proliferate (Wood and Bunge, 1975), and this neuronal mitogenic effect is prevented by interposition of a thin collagen membrane between neuron and Schwann cell

${ }^{1}$ Dr. Arthur Asbury, University of Pennsylvania, provided helpful suggestions and performed the transmission electron microscopic assessments of purity of the axolemmal fraction. Dr. Robert Barchi, University of Pennsylvania, provided us with the rat skeletal muscle sarcolemma. Dr. D. Schotland, University of Pennsylvania, helped to assess the surface area of cultured cells using a computer-assisted digitizer. The research was supported by the Muscular Dystrophy Association, Multiple Sclerosis Society, National Neurofibromatosis Society, and National Institutes of Health Grants NS08075, NS11037, and HD08536. G. S. was a Research Postdoctoral Fellow of the Muscular Dystrophy Association.

${ }^{2}$ To whom correspondence should be addressed, at Research Neurology, Children's Hospital of Philadelphia, 34th and Civic Center Boulevard, Philadelphia, PA 19104.
(Salzer et al., 1980b). These findings suggest that the neuronal Schwann cell mitogen is a plasma membrane-bound constituent which, in order to be effective, must be brought into intimate contact with the Schwann cell.

This hypothesis is supported by the observation that treatment of cultured Schwann cells with plasma membrane fragments prepared from CNS or PNS axons ("axolemmal fragments") elicits Schwann cell mitosis (DeVries et al., 1982, 1983b; Cassel et al., 1982; Sobue et al., 1983). This mitogenic effect is target specific; proliferation of cultured rat fibroblasts is not augmented by rat axolemmal fragments (Sobue et al., 1983). It is also signal specific; hepatic mitochondrial fragments, plasma membrane fragments prepared from non-neural tissues such as rat erythrocytes, liver or skeletal muscle fibers (DeVries et al., 1983, b; Sobue et al., 1983), a particulate fraction prepared from rat fibroblasts (Salzer et al., 1980a), or purified rat PNS myelin (Sobue et al., 1983) do not stimulate Schwann cell mitosis. However, the axolemmal mitogenic effect is not species specific; human and bovine axolemmal fragments elicit rat Schwann cell mitosis to an extent comparable to rat axolemmal fragments (DeVries et al., 1982; Sobue et al., 1984), and rat and human axolemmal fragments are of equivalent specific activity in stimulating proliferation of cultured human Schwann cells (Sobue et al., 1984). Axolemmal fragments lose the capacity to induce Schwann cell proliferation if subjected to trypsin digestion, sonication, vigorous homogenization, or 
heating (Salzer et al., 1980a, b; DeVries et al., 1982, 1983b; Sobue et al., 1983).

How is the mitogenic signal communicated by neuronal plasma membrane to Schwann cells? In the present study, we report that axolemmal fragments adhere to the surfaces of cultured Schwann cells in a saturable time- and temperaturedependent but extracellular calcium-independent process, and we demonstrate that this adhesive process is closely linked to subsequent axolemmal fragment-induced Schwann cell proliferation.

\section{Materials and Methods}

Cell cultures. Schwann cells were isolated from neonatal SpragueDawley rat sciatic nerves and cultured on the polylysine (Sigma Chemical Co.)-coated surfaces of either glass coverslips (for the radioautographic studies) or 96-well Falconware microtiter plates (for all other studies) in Eagle's minimum essential medium with Earle's salts (Grand Island Biological Co.) containing $10 \%$ calf serum (MEM-serum; Grand Island Biological Co.) (Kreider et al., 1981). The cultures were greater than $95 \%$ Schwann cells by indirect immunofluorescence criteria (Kreider et al., 1981). Fibroblasts were dissociated from the skin of near-term Sprague-Dawley rats and cultured on polylysine-coated surfaces in MEM-serum.

Preparation and characterization of axolemmal fragments from rat CNS. Myelinated axons isolated from adult female Sprague-Dawley rat cerebral white matter and brainstem were subjected to osmotic shock in $0.01 \mathrm{M} N$-tris(hydroxymethyl)methyl-2-aminoethanesulfonic acid and then fractionated on a 20 to $43 \%(\mathrm{w} / \mathrm{v})$ linear sucrose gradient (DeVries and Lazdunski, 1982; DeVreies et al., 1983a) by ultracentrifugation for $24 \mathrm{hr}$ at $5^{\circ} \mathrm{C}$ and $25,000 \mathrm{rpm}$ in a Sorvall SW27 rotor. Each gradient was resolved by aspiration into 12 fractions. Membrane fragments in the fractions were harvested by diluting the sucrose solution with 5 vol of water followed by ultracentrifugation (Sorvall ultracentrifuge, $5^{\circ} \mathrm{C}$ for $30 \mathrm{~min}$ at $\left.25,000 \mathrm{rpm}\right)$. Activities of the enzymes $\mathrm{Na}^{+} /$ $\mathrm{K}^{+}$-adenosine triphosphatase (Barnett, 1970), a plasma membrane marker, and cytochrome $c$ oxidase (Wharton and Tzagoloff, 1967), a mitochondrial inner membrane enzyme, were measured in each pellet, as were protein content (Lowry et al., 1951) and mitogenic activity for cultured Schwann cells. Selected fractions were also examined by transmission electron microscopy.

Other plasma membrane fractions. Erythrocyte plasma membrane fragments were prepared from adult female Sprague-Dawley rats as previously described (Sobue et al., 1983). Adult female Sprague-Dawley rat PNS myelin was prepared by two cycles of sucrose gradient ultracentrifugation and osmotic lysis (Norton and Poduslo, 1973). SpragueDawley rat skeletal muscle sarcolemma (Barchi et al., 1979) was a gift from Dr. Robert Barchi (Department of Neurology, University of Pennsylvania).

Assay for mitogenic activity. Cultured cells were incubated in polylysine-coated Falconware microtiter plate wells in $60 \mu \mathrm{l}$ of MEM-serum at $37^{\circ} \mathrm{C}$ in a $\mathrm{CO}_{2}$ incubator with axolemmal fragments or other plasma membrane fractions for $24 \mathrm{hr}$. Then, $0.2 \mu \mathrm{Ci}$ of tritiated thymidine (New England Nuclear; specific activity, $20 \mathrm{Ci} / \mathrm{mmol}$ ) was added in 40 $\mu \mathrm{l}$ of MEM-serum to each well. After an additional $24 \mathrm{hr}$ at $37^{\circ} \mathrm{C}$, the culture medium was replaced with ice-cold $140 \mathrm{mM} \mathrm{NaCl}, 5 \mathrm{~mm}$ potassium phosphate (PBS), $\mathrm{pH} 7.4$, and then with ice-cold $10 \%(\mathrm{w} / \mathrm{v})$ trichloroacetic acid (TCA) (Westermark, 1976). The wells were washed once with ice-cold $5 \%(\mathrm{w} / \mathrm{v})$ TCA and twice with PBS and then dried at room temperature. One hundred microliters of $2 \%(\mathrm{w} / \mathrm{v})$ sodium dodecyl sulfate in $0.3 \mathrm{~N} \mathrm{NaOH}$ were added to each well. The contents of the wells were harvested and radioactivity was determined in a liquid scintillation spectrometer using Aquasol II scintillation fluid (New England Nuclear). Control wells without cells or without added plasma membrane fractions were included on each microtiter plate and processed identically.

Radioiodination of axolemmal fragments and other plasma membrane fractions. Portions of the membrane fractions containing approximately $500 \mu \mathrm{g}$ of protein were incubated for $15 \mathrm{~min}$ at $25^{\circ} \mathrm{C}$ in PBS with 1 $\mathrm{mCi}$ of carrier-free ${ }^{125} \mathrm{I}$ (Amersham) in Pyrex test tubes on the walls of which $50 \mu \mathrm{g}$ of 1,3,4,6-tetrachloro-3a,6a-diphenylglycoluril (lodogen, Pierce Chemicals) had been deposited by evaporation from chloroform (Pleasure et al., 1982). After radioiodination, the membrane fractions were dialysed against sterile PBS for 3 days at $4^{\circ} \mathrm{C}$ or washed five times with PBS with harvesting between washes by ultracentrifugation
(Beckman air ultracentrifuge, room temperature, $87,000 \mathrm{rpm}$ for 20 $\min$ ). The labeled membrane fractions were stored at $-70^{\circ} \mathrm{C}$ for up to 3 weeks. Freezing and storage for this period had no effect on adhesion of radioiodinated axolemmal fragments to Schwann cells or the stimulation of incorporation of tritiated thymidine into TCA-precipitable material by unlabled axolemmal fragments.

Initial specific activity of axolemmal fragments radiolabeled by the Iodogen procedure varied between $8 \times 10^{4}$ and $1.4 \times 10^{6} \mathrm{cpm} / \mu \mathrm{g}$ of protein. Specific activity of sarcolemma was $9 \times 10^{5} \mathrm{cpm} / \mu \mathrm{g}$ of protein; that of erythrocyte plasma membrane fragments was $1.4 \times 10^{5} \mathrm{cpm} / \mu \mathrm{g}$ of protein; and that of PNS myelin was $2.7 \times 10^{5} \mathrm{cpm} / \mu \mathrm{g}$ of protein.

Modifications of axolemmal fragments. The effects of digestion of unlaheled or radioiodinated axolemmal fragments with trypsin and of heating or homogenization of the unlabeled or radioiodinated axolem. mal fragments (Sobue et al., 1983) on the mitogenic activity of axolemmal fragments and on the adhesion to Schwann cells of radioiodinated axolemmal fragments were compared.

Axolemmal fragments were incubated in $0.1 \%$ or $0.25 \%(\mathrm{w} / \mathrm{v})$ trypsin (Grand Island Biological $\mathrm{Cu}$.) in PBS at $37^{\circ} \mathrm{C}$ for the times indicated in the text; digestion was terminated by adding an equivalent amount of soybean trypsin inhibitor (Miles Laboratories), and the axolemmal fragments were washed with PBS and harvested by ultracentrifugation (Beckman air ultracentrifuge, room temperature, $87,000 \mathrm{rpm}$ for 20 $\mathrm{min})$. Control axolemmal fragments were incubated identically but in the absence of trypsin and then were treated with soybean trypsin inhibitor, washed, and harvested as above.

Axolemmal fragments were heated to $70^{\circ} \mathrm{C}$ or homogenized as previously described (Sobue et al., 1983).

Assay for adhesion of radioiodinated membrane fragments to cultured cells. Schwann cells or fibroblasts were cultured for $18 \mathrm{hr}$ in the polylysine-coated wells of 96 -multiwell test plates (Falcon Labware) and were used at a density of $2.5 \times 10^{4}$ cells/well. Radioiodinated membrane fragments were suspended in $60 \mu \mathrm{l}$ of MEM-serum with or without added EGTA at $37^{\circ} \mathrm{C}$ or $5^{\circ} \mathrm{C}$ as indicated in the text and figure legends. The microtiter plates bearing the cultures were brought to $37^{\circ} \mathrm{C}$ or $5^{\circ} \mathrm{C}$. The culture medium was removed, the cell monolayers were washed once with MEM-serum at the appropriate temperature, and then the medium was replaced by fresh medium at the same temperature which contained the membrane fragments. The plates were kept stationary for the times indicated in the text and figure legends, and then the medium was removed by aspiration. The cel layers were gently washed four times with PBS to remove unbound membrane fragments. Further PBS washes did not remove significant amounts of radioactivity from the cultures. The washed cells were then lysed with PBS/water $(1 / 9, v / v)$, and the contents of the wells were transferred to glass fiber disks by a MASH II cell harvester (Microbiological Associates) for scintillation spectrometry. Of total radioactivity in the wells containing cells, $70 \%$ was recovered by this cell lysis and harvesting procedure. Control polylysine-coated wells without cells but with MEM-serum were run in each experiment to determine the extent of binding of the radioiodinated membrane fragments to the well surfaces. Counts obtained with these control wells were from 7.3 to $9.5 \%$ of those with cell-containing wells.

Autoradiography and indirect immunofluorescence. To compare the binding of axolemmal fragments to Schwann cells and to fibroblasts in mixed Schwann cell-fibroblast cultures, newly isolated Schwann cells were mixed with a varying proportion of dermal fibroblasts which had been harvested by trypsinization. The mixed cell populations and pure cultures of Schwann cells and of dermal fibroblasts were seeded on polylysine-coated glass coverslips in MEM-serum. Eighteen hours later, the medium was changed to fresh MEM-serum containing radioiodi nated axolemmal fragments. After $8 \mathrm{hr}$, the coverslips were removed from the medium and processed for indirect immunofluorescent demonstration of fibroblast surface fibronectin (Wartiovadra et al., 1974); then they were washed repeatedly with PBS, fixed with $5 \%$ acid alcohol in PBS (pH 7.4) for $10 \mathrm{~min}$ at $4^{\circ} \mathrm{C}$, rinsed with water, dipped in NTB2 emulsion (Eastman Kodak), exposed for 4 days at $5^{\circ} \mathrm{C}$, and developed. Some of the coverslips were stained with $0.3 \%$ toluidine blue in PBS after development of the emulsion.

\section{Results}

Properties of the axolemmal fragments. The membrane fragments obtained in fractions 5 and 6 of the continuous sucrose gradient (see "Materials and Methods") were found to be highest in $\mathrm{Na}^{+}, \mathrm{K}^{+}$-ATPase specific activity and Schwann cell mi- 


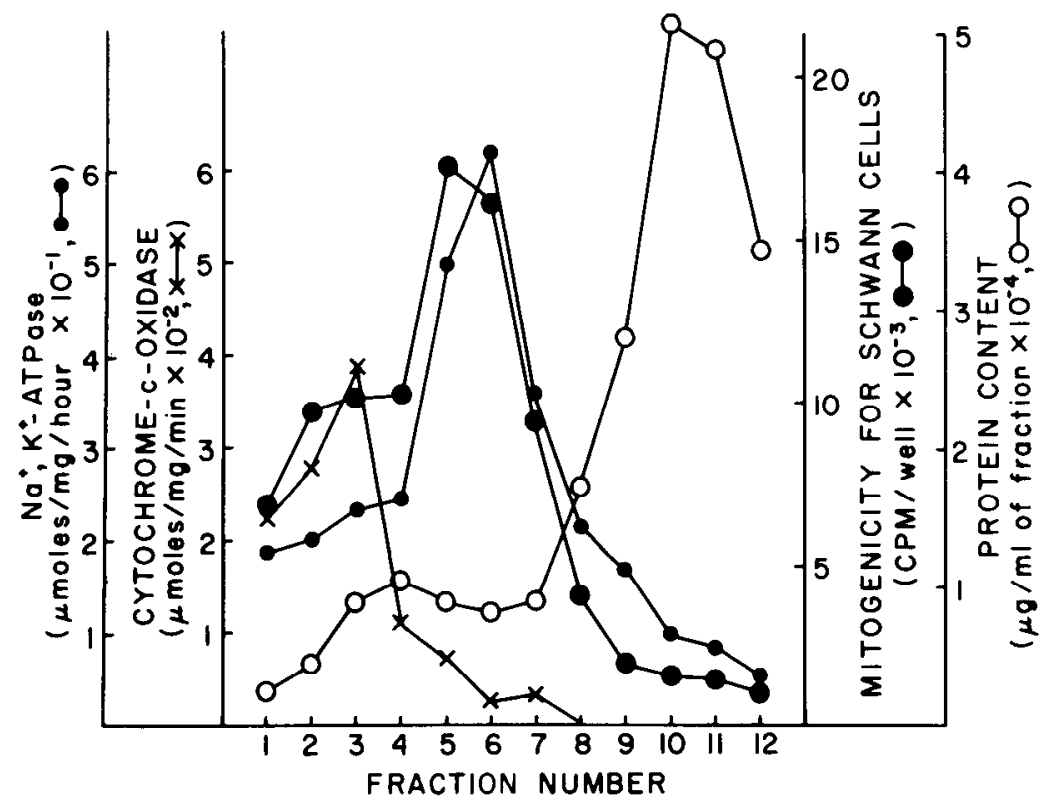

Figure 1. Purification of axolemmal fragments from osmotically shocked myelinated CNS axons by continuous sucrose gradient ultracentrifugation. Myelinated ax ons were isolated and subjected to osmotic shock, applied to a linear sucrose gradient, and ultracentrifuged, and the gradient was harvested in 12 fractions as described under "Materials and Methods." Each fraction was assayed for $\mathrm{Na}^{+}, \mathrm{K}^{+}$-ATPase (Barnett, 1970), cytochrome $c$ oxidase (Wharton and Tzagoloff, 1967), protein (Lowry et al., 1951), and mitogenicity for Schwann cells (Sobue et al. 1983) using $8 \mu \mathrm{g}$ of protein from the fraction for each Schwann cell-containing microtiter plate well.

togenic specific activity and relatively low in cytochrome $c$ oxidase (Fig. 1). Electron microscopy showed fractions 5 and 6 to contain chiefly 0.1 - to $1.5-\mu \mathrm{m}$-diameter vesicles without visible contents. There were occasional membranes recognizable as derived from organelles other than axolemma. These included mitochondrial inner membrane fragments with associated cristae, multilamellar myelin fragments, and synaptosomes retaining interior neurotransmitter vesicles. These contaminating particles did not make up more than $10 \%$ of the total membrane fragments in any field examined.

Adhesion of radioiodinated axolemmal fragments to cultured rat Schwann cells. When Schwann cell, fibroblast, or mixed Schwann cell-dermal fibroblast cultures were incubated with radioiodinated axolemmal fragments for $8 \mathrm{hr}$ and then washed, almost all of the Schwann cells were uniformly covered with silver grains, whereas the fibroblasts showed only background levels of silver grains (Fig. 2). Similar results were observed when Schwann cell cultures containing 2 to $5 \%$ endoneurial fibroblasts were examined by these methods (results not shown). These qualitative observations indicated that, within $8 \mathrm{hr}$, axolemmal fragments adhere to Schwann cells but not fibroblasts, in a manner that cannot thereafter be disrupted by repetitive washing with $\mathrm{PBS}$.

To obtain quantitative data on this adhesive phenomenon, the axolemmal fragments were added to microtiter plate wells containing Schwann cells or fibroblasts. The incubation time, incubation temperature, concentration of axolemmal fragments added, and ionized calcium concentration in the medium were varied, the cells were then washed and lysed, and radioactivity associated with the lysates was quantitated. Figure 3 shows the time course of adhesion of the radioiodinated axolemmal frayments to the Schwann cells and to dermal fibroblasts at $37^{\circ} \mathrm{C}$. Since the binding was largely to the surfaces of the cells (Grumet et al., 1983, 1984), surface areas of the Schwann cell and fibroblast cultures were estimated by computer-assisted analyses and binding data were expressed in counts per minute per square millimeter of cell surface. The Schwann cells bound at least 7 -fold more radioactivity per unit surface area than did the fibroblasts at each time point examined. In one such experiment, we calculated that maximal binding of the radioiodinated axolemmal fragments under these conditions was $3.3 \mathrm{pg}$ of axolemmal fragment protein/Schwann cell and $1.4 \mathrm{pg}$ of axolemmal fragment protein/fibroblast.

The adhesive process demonstrated signal specificity; using
Schwann cells as the targets, only about one-fifth as much sarcolemmal or erythrocyte plasma membrane protein adhered as did axolemmal fragment protein. Binding of PNS myelin protein to the Schwann cells was higher, but still only a fraction of that observed with axolemmal fragments. (Fig. 4).

Adhesion of the radioiodinated axolemmal fragments to the Schwann cells reached a plateau level at $4 \mathrm{hr}$, and half-maximal adhesion to the Schwann cells was reached at $1 \mathrm{hr}$. When this time course experiment was repeated with the same amount of radioiodinated axolemmal fragments at $4^{\circ} \mathrm{C}$, one-third to half as many radioiodinated axolemmal fragments adhered to the Schwann cells at each time point as at $37^{\circ} \mathrm{C}$, and adhesion had not reached a plateau at the end of $4 \mathrm{hr}$ of incubation (Fig. 5).

To examine the concentration dependence of the axolemmal fragment-Schwann cell adhesive process, Schwann cells were incubated with varying amounts of radioiodinated axolemmal fragments at $37^{\circ} \mathrm{C}$ for $4 \mathrm{hr}$. Maximal adhesion occurred with addition of axolemmal fragments equivalent to $16 \mu \mathrm{g}$ of protein or more to each well, and half-maximal adhesion was with $4 \mu \mathrm{g}$ of axolemmal fragment protein/well (Fig. 6). Based upon the specific activity of the radioiodinated axolemmal fragments, we calculated that $1.6 \%$ of the axolemmal fragment protein added to the medium adhered to the Schwann cells when $32 \mu \mathrm{g}$ of axolemmal fragment protein were added to the wells, and $8.2 \%$ of the axolemmal fragment protein adhered to the Schwann cells when $0.5 \mu$ of axolemmal fragment protein was added to the wells.

To determine whether extracellular ionized calcium is required for adhesion of radioiodinated axolemmal fragments to Schwann cells, Schwann cell monolayers were preincubated for 15 min in MEM-serum containing $3 \mathrm{~mm}$ EGTA. Then the medium was changed to MEM-serum containing $3 \mathrm{~mm}$ EGTA and radioiodinated axolemmal fragments. Control wells were treated identically except that there was no exposure to EGTA. After $4 \mathrm{hr}$ at $37^{\circ} \mathrm{C}$, the cell layers were washed, lysed, and harvested as above. EGTA did not alter the amount of radioiodinated axolemmal fragments bound to the Schwann cells (Table I). Since the estimated ionized calcium concentration in MEM-serum without EGTA was less than $2 \mathrm{mM}$ and that in MEM-serum containing $3 \mathrm{mM}$ EGTA was below $1 \mu \mathrm{M}$, this experiment indicated that adhesion of axolemmal fragments to cultured Schwann cells is not dependent upon the presence of ionized calcium in the medium.

Two mechanisms could explain this time- and temperature- 

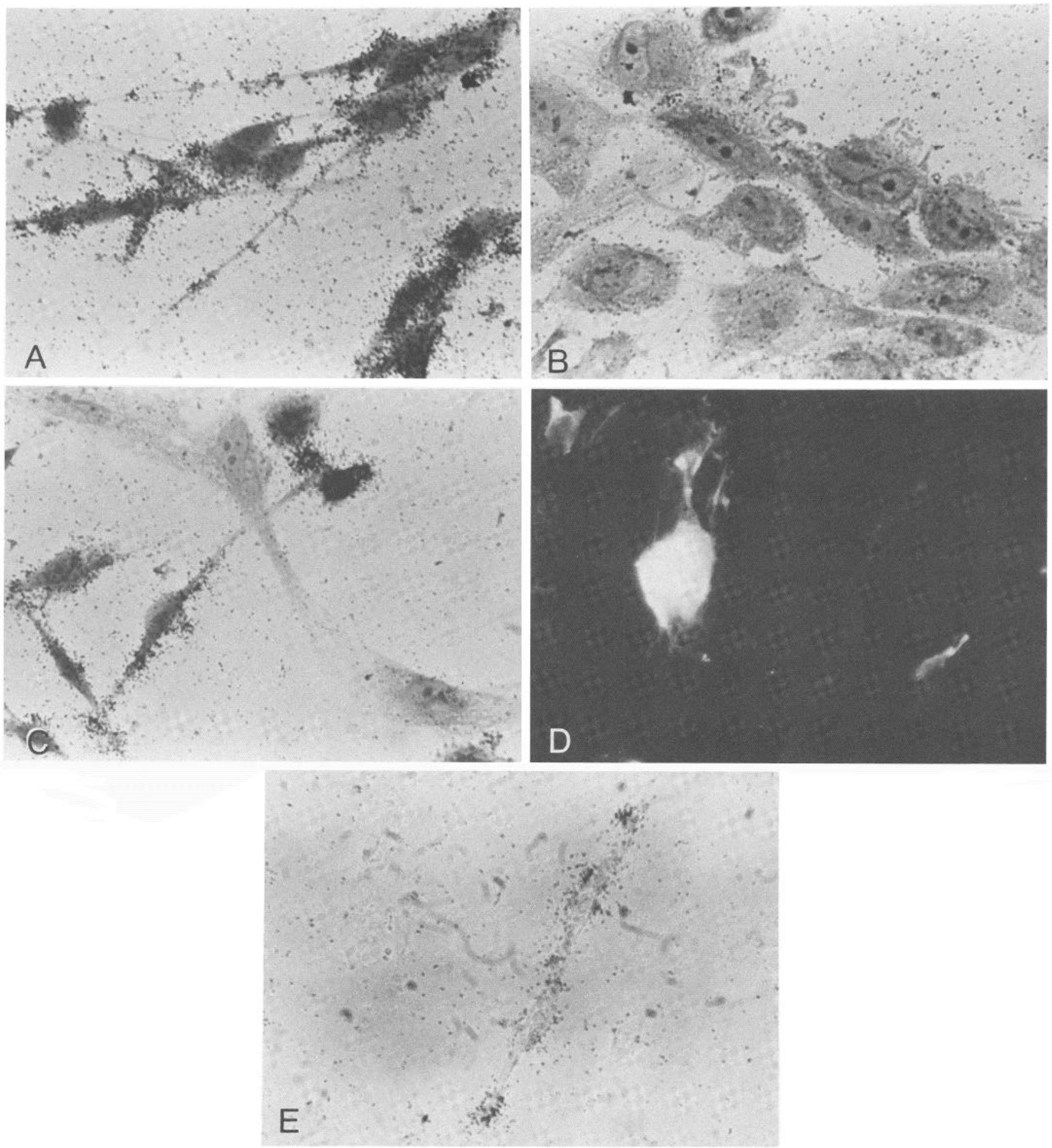

Figure 2. Autoradiographic demonstration of the binding of ${ }^{125}$ I-labeled axolemmal fragments to cultures of Schwann cells, of fibroblasts, and to mixed Schwann cell-fibroblast cultures. Rat Schwann cells and rat dermal fibroblasts were cultured on 13-mm-diameter polylysine-coated glass coverslips in 16-mm-diameter Falcon wells. Each well contained $0.5 \mathrm{ml}$ of Eagle's MEM with $10 \%$ (v/v) calf serum. Radioiodinated axolemmal fragments (18 $\mu \mathrm{g}$ of axolemmal fragment protein/coverslip) were added $8 \mathrm{hr}$ before termination of the cultures. $A$, Schwann cell culture radioautographed and stained with toluidine blue. Abundant radioactivity is associated with the Schwann cells. $B$, Fibroblast culture radioautographed and stained with toluidine blue. The density of silver grains over the fibroblasts is near background level. $C$, Mixed Schwann cell-fibroblast culture radioautographed and stained with toluidine blue. Spindle-shaped Schwann cells are heavily radiolabeled, whereas the fibroblasts are labeled at near background level. $D$ and $E$, Mixed Schwann cell-fibroblast culture radioautographed and examined by indirect immunofluorescence with anti-fibronectin antiserum. $D$, Immunofluorescence; $E$, corresponding field examined by brightfield microscopy, with focus adjusted to silver grain layer. The slender, fibronectin-negative Schwann cells (Kreider et al., 1981; Cornbrooks et al., 1983) are heavily radiolabeled, whereas the fibronectin-positive fibroblasts (Wartiovaara et al., 1974) are near background radiolabeling. Processing for detection of anti-fibronectin immunoglobulin binding by indirect immunofluorescence and for autoradiography are described under "Materials and Methods." 


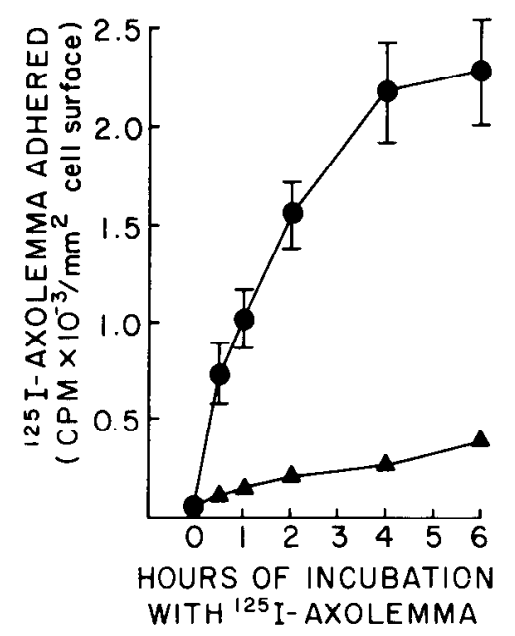

Figure 3. Time course of adhesion of radioiodinated axolemmal fragments to Schwann cells and epidermal fibroblasts. Polylysinecoated Falcon microtiter wells were seeded with $2.5 \times 10^{4}$ Schwann cells or $0.64 \times 10^{4}$ fibroblasts. Radioiodinated axolemmal fragments $\left(0.5 \mu \mathrm{g}\right.$ of protein/well; $1.2 \times 10^{\mathrm{K}} \mathrm{cpm} / \mu \mathrm{g}$ of protein) were added $18 \mathrm{hr}$ after initiation of the cultures, cells in the wells were washed and harvested, and bound radioactivity was determined as described under "Materials and Methods." Results were expressed as counts per minute per square millimeter of cell surface area $(\boldsymbol{C}$, Schwann cells; $\boldsymbol{\Delta}$, fibroblasts). In order to estimate cell surface area, parallel wells were fixed

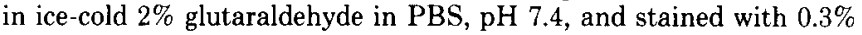
$(\mathrm{w} / \mathrm{v})$ toluidine blue in PBS for $1 \mathrm{~min}$ at $25^{\circ} \mathrm{C}$. The stained wells were filled with glycerol/water $(1 / 1, \mathrm{v} / \mathrm{v})$ and photographs were immediately taken along one diameter of the wells. Prints at $\times 1150$ magnification were analyzed with a computer-assisted digitizer. Results are the means and standard deviations of four determinations.

dependent association of radioiodinated axolemmal fragments with Schwann cells. Axolemmal fragments might be binding to receptors on the surfaces of the Schwann cells, or Schwann cells might rapidly internalize axolemmal fragments. To discriminate between these possibilities, the Schwann cells were exposed to radioiodinated axolemmal fragments at $37^{\circ} \mathrm{C}$ for 0 to $24 \mathrm{hr}$ and then were washed four times with PBS. The washed monolayers were then treated with $0.25 \%$ trypsin (w/ $\mathrm{v}$ ) in PBS for $15 \mathrm{~min}$ at $37^{\circ} \mathrm{C}$. Then the cells were spun down and reseeded in the wells. As soon as the cells became attached (approximately $30 \mathrm{~min}$ ), they were harvested, and cell-associated radioactivity was determined. Of the radioactivity bound to non-trypsinized cells, $3.2 \%$ remained bound after trypsinization at $6 \mathrm{hr}$, and $6.3 \%$ remained bound after trypsinization at $24 \mathrm{hr}$ (Fig. 7). Since the time course experiments (Fig. 3) had indicated that a plateau of maximal binding of radioiodinated axolemmal fragments is reached by $4 \mathrm{hr}$, and since it is unlikely that trypsin could have penetrated into the interior of the Schwann cells but left them viable, the results of these trypsinization experiments indicate that, at $4 \mathrm{hr}$, when maximal binding of axolemmal fragments to the Schwann cells had occurred, the vast majority of the bound radiolabeled axolemmal fragments remained on the surface of the Schwann cells, not sequestered within the cell interior.

Correlations between adhesion of axolemmal fragments to Schwann cells and axolemmal fragment-induced stimulation of Schwann cell tritiated thymidine incorporation. To study the linkage between binding of axolemmal fragments to the Schwann cell surface and subsequent Schwann cell mitosis, we employed mild tryptic digestion as described above to remove non-radiolabeled axolemmal fragments from Schwann cells at intervals between 0 and $24 \mathrm{hr}$ after their addition to the medium. The Schwann cells were then replated in MEM-serum, tritiated thymidine was added $24 \mathrm{hr}$ after first contact with axolemmal fragments, and tritiated thymidine incorporation

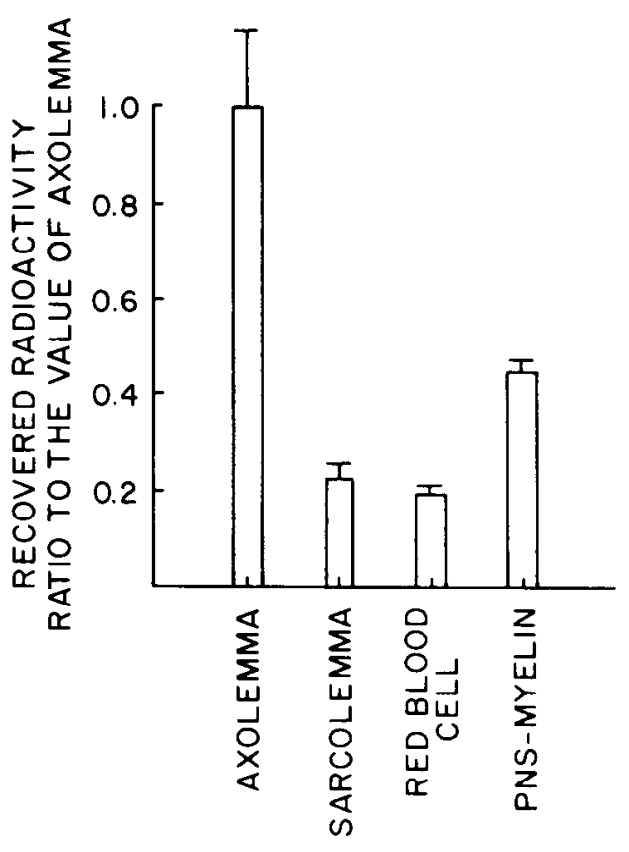

Figure 4. Adhesion of various radioiodinated plasma membrane fractions to Schwann cells. Radioiodinated axolemmal fragments, sarcolemma, erythrocyte plasma membrane fragments, or PNS myelin equivalent to $2 \mu \mathrm{g}$ of protein were added to Schwann cells cultured as described in the legend to Figure 3 . The microtiter plates were incubated at $37^{\circ} \mathrm{C}$ for $4 \mathrm{hr}$; the cells were then washed and harvested, and adherent radioactivity was assayed as described under "Materials and Methods." Results were corrected for radioactive specific activities of the various membrane fractions and are expressed as the ratio of micrograms of the membrane fraction bound to micrograms of axolemmal fragments bound. The results are the means of five determinations with vertical bars indicating standard deviations.

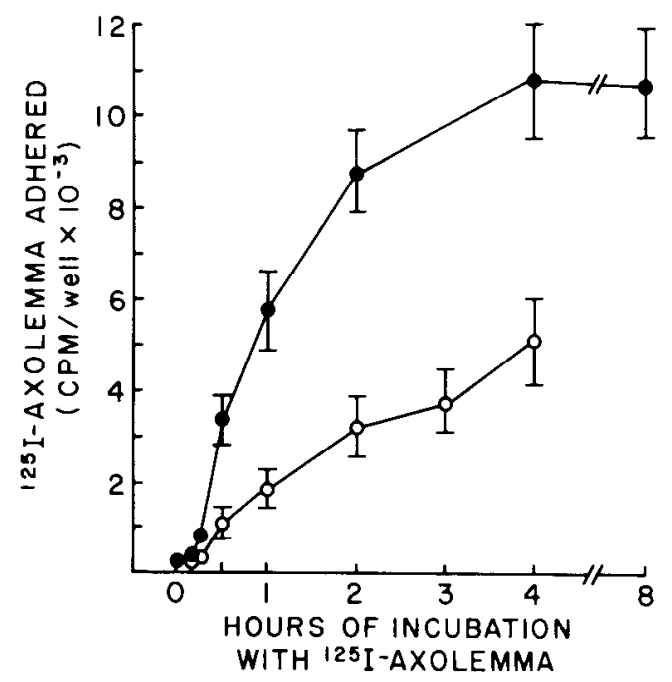

Figure 5. Effects of temperature on time course of adhesion of radioiodinated axolemmal fragments to Schwann cells. Schwann cells were seeded and maintained as described in the legend to Figure 3. Radioiodinated axolemmal fragments $(1 \mu \mathrm{g})$ of protein/well; specific activity, $1 \times 10^{5} \mathrm{cpm} / \mu \mathrm{g}$ of protein) were added $18 \mathrm{hr}$ after initiation of culture. After addition of the axolemmal fragments, temperature was maintained at $37^{\circ} \mathrm{C}(\boldsymbol{O})$ or $5^{\circ} \mathrm{C}(0)$ ). Cells were harvested at intervals and bound radioactivity was determined by scintillation spectrometry as described under "Materials and Methods." Results are means and standard deviations of four determinations. 


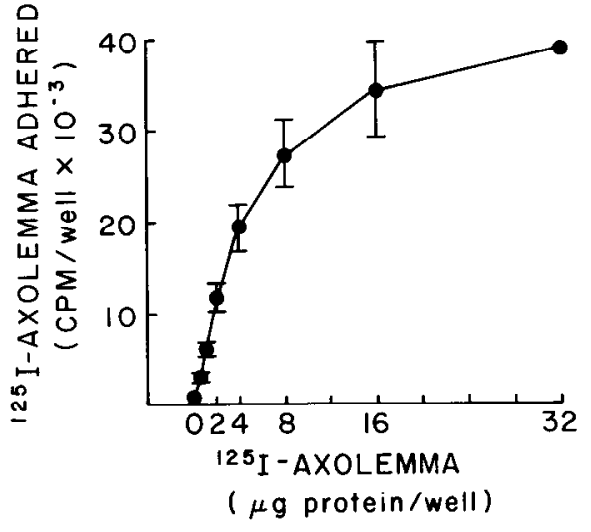

Figure 6. Dose dependence of adhesion of radioiodinated axolemmal fragments to Schwann cells. The Schwann cells were seeded and cultured in Eagle's MEM with $10 \%(\mathrm{v} / \mathrm{v})$ calf serum in the polylysinecoated wells of Falcon 96 -well microtiter plates at a density of $2.5 \times$ $10^{4}$ cells/well. Radioiodinated axolemmal fragments (specific activity, $7.1 \times 10^{4} \mathrm{cpm} / \mu \mathrm{g}$ of protein) were added to the wells at $18 \mathrm{hr}$ after the cultures were initiated. After $4 \mathrm{hr}$ at $37^{\circ} \mathrm{C}$ in a $\mathrm{CO}_{2}$ incubator without shaking, the wells were washed with PBS as described under "Materials and Methods," and then the cells were harvested using a MASH II cell harvester. Radioactivity adhering to the cells was quantitated by scintillation spectrometry, and results are expressed as mean and standard deviation of four determinations.

\section{TABLE I}

Effect of EGTA on adhesion of axolemmal fragments to Schwann cells

Schwann cells were seeded and maintained as described in the legend to Figure 3 and under "Materials and Methods." The Schwann cells were equilibrated with media containing the concentrations of EGTA indicated for $15 \mathrm{~min}$ before addition of the axolemmal fragments. Then, radioiodinated axolemmal fragments $(2 \mu \mathrm{g}$ of axolemmal fragment protein/well, specific activity, $1.0 \times 10^{5} \mathrm{cpm} / \mu \mathrm{g}$ of protein), suspended in media containing the indicated concentrations of EGTA, were added and the cultures were maintained for $4 \mathrm{hr}$ at $37^{\circ} \mathrm{C}$, washed, and harvested as described under "Materials and Methods." The ionized calcium concentration in MEM-serum without EGTA was below $2 \mathrm{mM}$, and that in MEM-serum containing $3 \mathrm{mM}$ EGTA was estimated to be below $1 \mu \mathrm{M}$.

\begin{tabular}{cc}
\hline EGTA (mM) & $\begin{array}{c}{ }^{12} \text { I-Axolemmal Fragments } \\
\text { Bound (cpm/well) }\end{array}$ \\
\hline 0 & $22,153 \pm 3,210(8)^{a}$ \\
1.0 & $20,688 \pm 879(6)$ \\
2.8 & $18,850 \pm 2,428(8)$ \\
3.0 & $23,689 \pm 2,226(8)$ \\
\hline
\end{tabular}

${ }^{a}$ Results are expressed as means \pm standard deviations for the numbers of determinations indicated in parentheses.

into TCA-insoluble material was determined $24 \mathrm{hr}$ thereafter. Treatment of the Schwann cells with axolemmal fragments for $4 \mathrm{hr}$ caused no increase in tritiated thymidine incorporation over that by control cells not exposed to axolemmal fragments (Fig. 8). Six or $8 \mathrm{hr}$ of exposure to axolemmal fragments resulted in a minimal increase in tritiated thymidine incorporation by the cells, but the full mitogenic response required that $24 \mathrm{hr}$ or more pass between addition of the axolemmal fragments to the medium and their removal by trypsinization of the Schwann cells (Fig. 8).

It has previously been demonstrated that homogenization, sonication, heating, or trypsinization of axolemmal fragments before their application to Schwann cell cultures results in a marked diminution in mitogenic activity of the axolemmal fragments (Salzer et al., 1980b; Cassel et al., 1982; DeVries et al., 1982, 1983b; Sobue et al., 1983). We wished to determine whether these treatments also inhibited the adhesion of axo-

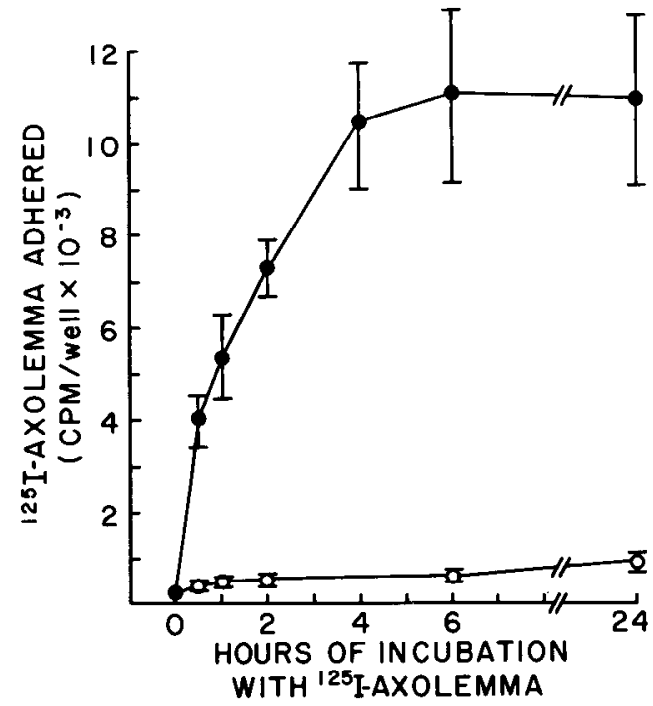

Figure 7. Release of radioactivity from Schwann cells which had been incubated with radiolabeled axolemmal fragments by brief trypsinization. Schwann cells were seeded and cultured as described in the legend to Figure 3. Eighteen hours after seeding, radioiodinated axolemmal fragments ( $1 \mu \mathrm{g}$ of axolemmal fragment protein/well) were added; then, the wells were incubated at $37^{\circ} \mathrm{C}$ for the times indicated, washed with PBS, incubated with $0.25 \%$ (w/v) trypsin in PBS for 15 min at $37^{\circ} \mathrm{C}$, and then harvested and resuspended in ice-cold Eagle's MEM with $10 \%$ calf serum. The cell suspensions were centrifuged at 1500 rpm for $5 \mathrm{~min}$ in a Sorvall $\mathrm{HG} 4 \mathrm{~L}$ rotor at $5^{\circ} \mathrm{C}$, and cells were reseeded to other wells. Most of the cells attached to the new wells in $30 \mathrm{~min}$ and began to extend processes by $1 \mathrm{hr}$. As soon as the cells were attached, the cell layer was washed gently with PBS and then harvested. Radioactivity associated with the cells was determined by scintillation spectrometry. By use of a Coulter counter, we determined that the number of cells obtained by harvesting after this reseeding procedure was $66 \%$ of the number obtained by harvesting without reseeding. Results are expressed as means and standard deviations of four determinations.

lemmal fragments to Schwann cells. Results indicated a close parallelism between the effects of these treatments on adhesion of radioiodinated axolemmal fragments to Schwann cells and specific mitogenic activity of the treated axolemmal fragments (Fig. 9). Trypsin exposure, homogenization, and heating produced declines in adhesion and in mitogenic activity of similar degree. From these observations, and by comparing the concentration dependence of adhesion of axolemmal fragments to Schwann cells (Fig. 6) with concentration dependence of mitogenic activity of axolemmal fragments for Schwann cells (Fig. 10), it appears that the process of adhesion of axolemmal fragments to Schwann cells and the mitogenic response of Schwann cells to axolemmal fragments are closely linked.

\section{Discussion}

Neurons regulate certain aspects of neuroglial metabolism. Examples of such neuronal trophic effects are: the initiation of myelin synthesis by Schwann cells (Aguayo et al., 1976; Weinberg and Spencer, 1976; Bunge and Bunge, 1978) and oligodendroglia (Wood et al., 1980; Seil and Blank, 1981; Mithen et al., 1983), the induction of type IV collagen synthesis and basal lamina deposition by Schwann cells (Bunge et al., 1980, 1982; Carey et al., 1983; Cornbrooks et al., 1983), facilitation of glucocorticoid induction of glutamine synthetase in retinal Müller cells (Linser and Moscona, 1979, 1983), and stimulation of Schwann cell mitosis (Wood and Bunge, 1975; McCarthy and Partlow, 1976; Hanson and Partlow, 1978; Salzer et al., $1980 \mathrm{a}, \mathrm{b})$. A common feature of these neuronal regulatory effects is the requirement for close contact between neuron and 


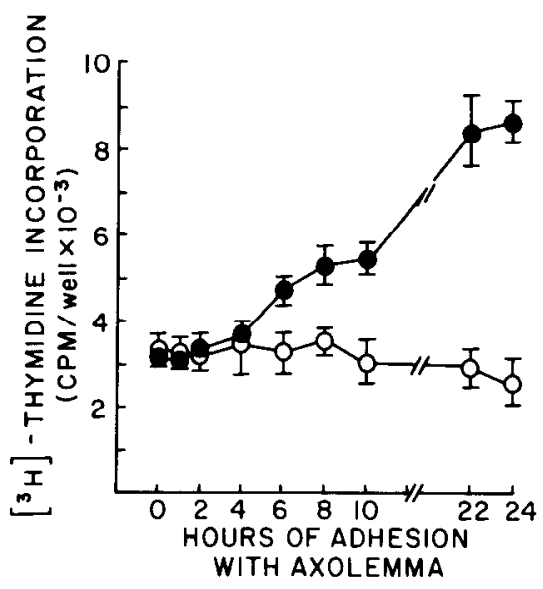

Figure 8. Relationship between duration of adhesion of the axolemmal fragments to Schwann cells and Schwann cell proliferation. Schwann cells were seeded and cultured as described in the legend to Figure 3. Fresh Eagle's MEM with $10 \%$ calf serum with or without axolemmal fragments ( $8 \mu \mathrm{g}$ of axolemmal fragment protein/well) was added $18 \mathrm{hr}$ after initiation of culture. At intervals between 0 and 24 $\mathrm{hr}$ later, brief trypsinization, cell harvesting, and washing were performed as described in the legend to Figure 7 . Then the cells were reseeded in polylysine-coated Falcon microtiter plate wells in Eagle's MEM with $10 \%(\mathrm{v} / \mathrm{v})$ calf serum. The trypsinization, washing, and reseeding caused a loss of about $30 \%$ of the cells. Twenty-four hours after first contact of each culture with axolemmal fragments, $0.2 \mu \mathrm{Ci}$ of tritiated thymidine (New England Nuclear; specific activity, $20 \mathrm{Ci}$ / $\mathrm{mmol}$ ) was added. The incubations were terminated $24 \mathrm{hr}$ after addition of the tritiated thymidine by removal of the medium and its replacement with ice-cold $10 \% \mathrm{TCA}(\mathrm{w} / \mathrm{v})$ in water. Incorporation of the tritiated thymidine into TCA-precipitated material was determined as described under "Materials and Methods." Note that the incorporation of tritiated thymidine into control cultures was considerably higher than in untrypsinized control cultures (generally less than $1000 \mathrm{cpm} /$ well), probably as a consequence of the trypsin treatment (Kalderon, 1982).

neuroglial cell. The necessity for establishment and maintenance of these close contacts between neurons and neuroglia implies the existence of cell type-specific adhesive mechanisms (Edelman, 1983; Grumet et al., 1983, 1984).

Neuronal plasma membrane vesicles, like intact neurons, adhere to CNS neuroglia in tissue culture and do so by a process involving a neuronal cell surface sialoglycoprotein (Grumet et al., 1983, 1984). Furthermore, plasma membrane fragments prepared from myelinated axons, like intact axons, have the capacity to stimulate Schwann cell mitosis (Cassel et al., 1982; DeVries et al., 1982, 1983b; Sobue et al., 1983). Membrane fragments from the $\mathrm{PCl} 2$ line were also recently reported to be mitogenic for cultured Schwann cells (Ratner et al., 1984). The addition of such neuronal plasma membrane fragments to monolayer cultures of purified neuroglia affords a simplified model system for the study of neuronal-neuroglial trophic interactions.

The present study demonstrates that radioiodinated axolemmal fragments adhere to cultured Schwann cells by a process which is concentration, time, and temperature dependent, but independent of extracellular ionized calcium. Adhesion of radioiodinated axolemmal fragments to Schwann cells reaches a plateau level within $4 \mathrm{hr}$ at $37^{\circ} \mathrm{C}$. At this time point, $97 \%$ of the bound radioactivity can be released from the Schwann cells by brief trypsinization without loss of cellular viability. This result indicates that initial adhesion of the axolemmal fragments is to the Schwann cell surface. Even $24 \mathrm{hr}$ after application of the radioiodinated axolemmal fragments to the Schwann cells, $94 \%$ of bound radioactivity can be released by brief trypsinization. The remaining, trypsin-stable radioactiv-
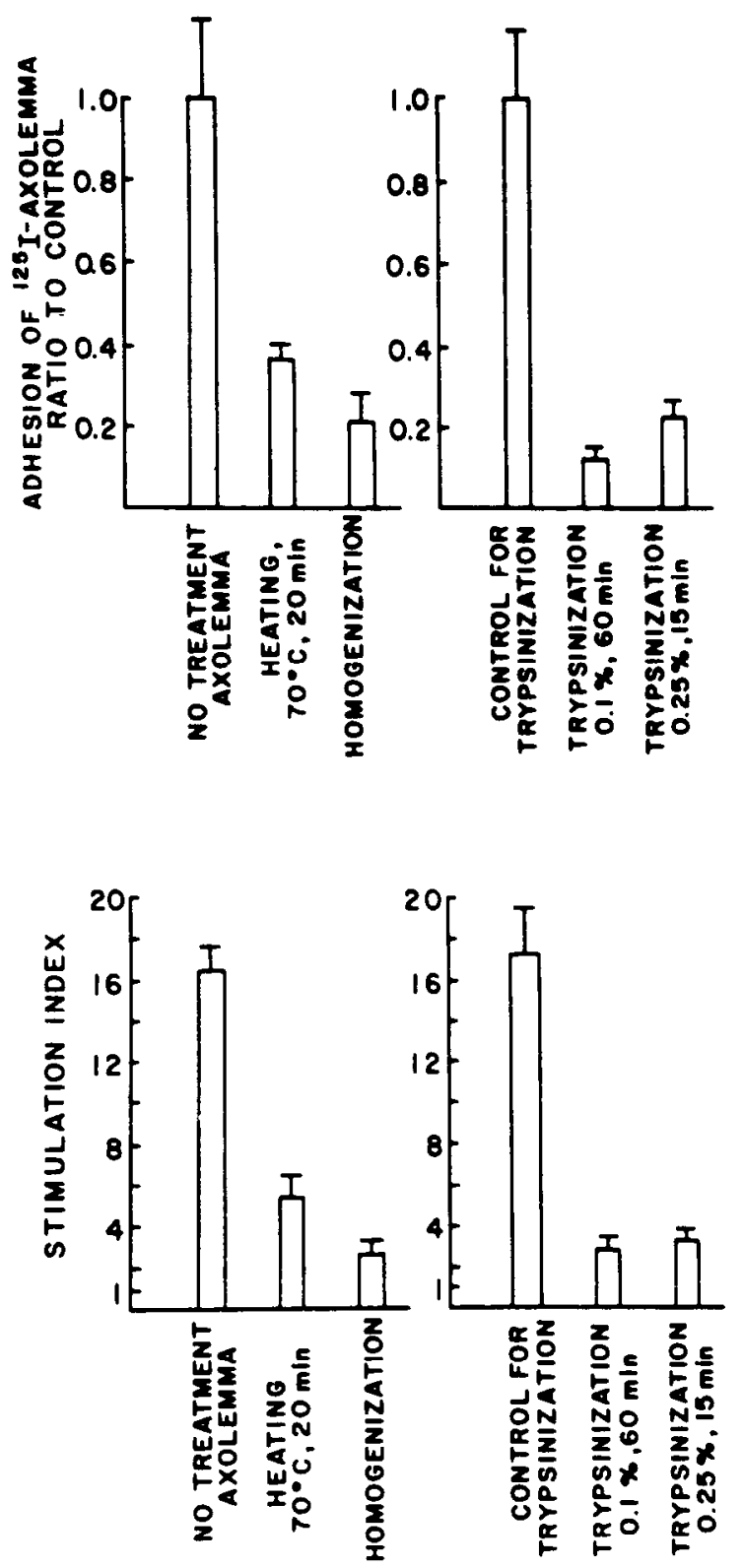

Figure 9. Effects of heating, homogenization, and trypsinization on adhesion of radioiodinated axolemmal fragments to Schwann cells and on Schwann cell mitogenic activity of axolemmal fragments. Axolemmal fragments (radioiodinated for the adhesion assays) were heated or homogenized as previously described (Sobue et al., 1983). The trypsinization procedure is described under "Materials and Methods" and, for the adhesion assays, were carried out subsequent to radioiodination. For the adhesion studies, axolemmal fragments equivalent to $1 \mu \mathrm{g}$ of protein were added to each well. For the tritiated thymidine incorporation studies, axolemmal fragments equivalent to $8 \mu \mathrm{g}$ of protein were added to each well. Results are the means of five determinations, with vertical bars indicating standard deviation.

ity may be attributable to phagocytosis by the Schwann cells of a small proportion of the axolemmal fragments (Salzer et al., 1980a).

We observed many parallels between axolemmal adhesion to Schwann cells and axolemmal induction of Schwann cell mitosis. The concentration of axolemmal fragments required for half-saturation of adhesion to Schwann cells and for halfmaximal stimulation of tritiated thymidine incorporation by the Schwann cells were the same (Fig. 10). Trypsinization, heating, or vigorous homogenization of axolemmal fragments diminished adhesion of the treated axolemmal fragments to 


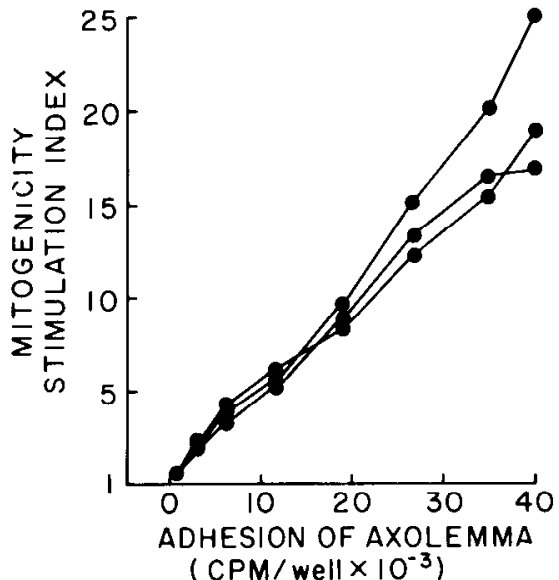

Figure 10. Comparison between concentration dependence of axolemmal adhesion to Schwann cells and concentration dependence of Schwann cell mitogenic response to axolemmal fraction. The points shown were calculated from the results described in the legend to Figure 6 and from three independent experiments in which axolemmal mitogenic activity for Schwann cells was determined (as described under "Materials and Methods") as a function of the amount of axolemmal fraction added ( 0 to $32 \mu \mathrm{g}$ of protein/well; each experiment utilized four wells at each concentration of axolemmal fraction tested). The basal level of $\left[{ }^{3} \mathrm{H}\right]$ thymidine incorporation in these experiments ranged between 550 and $930 \mathrm{cpm} /$ well, whereas the maximal stimulation level ranged between 12,000 and $18,000 \mathrm{cpm} /$ well. A linear relationship was observed between amount of radioiodinated axolemmal fraction adhering to the cultured Schwann cells and Schwann cell mitogenic response.

Schwann cells and the Schwann cell mitogenic response to these fragments to a similar degree. Both the adhesive and mitogenic processes exhibited signal and target specificity; other plasma membrane preparations did not adhere to Schwann cells to the same extent as did axolemmal fragments, nor did they stimulate Schwann cell mitosis, and axolemmal fragments did not adhere to fibroblasts to the same extent as to Schwann cells or stimulate fibroblast proliferation (Sobue et al., 1983, 1984).

These qualitative and quantitative parallels between the processes of adhesion of axolemmal fragments to Schwann cells and induction of Schwann cell mitosis strongly suggest that adhesion of the axolemmal fragments is an early, necessary step in triggering of Schwann cell proliferation. An important implication of this is that it is not necessarily true, as we and others previously assumed (Hanson and Partlow, 1978; Salzer et al., 1980a, b; Cassel et al., 1982; DeVries et al., 1982; Sobue et al., 1983), that the axolemmal mitogen is trypsin, mechanically, and heat labile. Instead, because these treatments inactivate the adhesive mechanism, an axolemmal mitogen intrinsically resistant to these treatments may not be brought into necessary contact with the appropriate Schwann cell receptor. The deleterious effects of homogenization and heat on the ability of axolemmal fragments to adhere to Schwann cells could either reflect mechanical and thermal lability of the adhesive component or could be a consequence of a re-orientation of this component in the axolemmal membrane that prevents contact with the Schwann cell surface.

Although adhesion of axolemmal fragments to Schwann cells appears necessary for axolemma-induced stimulation of Schwann cell mitosis, it is not sufficient to deliver an immediate and irreversible signal for Schwann cell mitosis. This is demonstrated by the observation that, although adhesion is rapid, reaching a maximum within $4 \mathrm{hr}$ of addition of the axolemmal fragments to the Schwann cell cultures, Schwann cell-axolemmal contact must be sustained for at least $6 \mathrm{hr}$ and optimally for $24 \mathrm{hr}$ or more to induce DNA replication. Phagocytosis of axolemmal fragments by Schwann cells does occur (Salzer et al., 1980a), but it is neither entirely dependent upon the rapid adhesive process described in the present paper nor in itself sufficient to trigger Schwann cell mitosis, since Schwann cells have been noted to ingest axolemmal fragments which were previously trypsinized (Salzer et al., 1980a) and hence both far less able to adhere to Schwann cells and far less able to induce Schwann cell mitosis.

Axolemmal fragments can substitute for intact neurons to stimulate Schwann cell proliferation, and the present paper provides evidence that signal- and target-specific adhesion of axolemmal fragments to the surface of Schwann cells is an essential early stage in this process. Further studies will be necessary to characterize the adhesive and mitogenic components of axolemmal membrane.

\section{References}

Aguayo, A., L. Charron, and G. Bray (1976) Potential of Schwann cells from unmyelinated nerves to produce myelin: A quantitative ultrastructural and radiographic study. J. Neurocytol. 5: 565-573.

Barchi, R., J. B. Weigele, B. M. Chalikian, and L. E. Murphy (1979) Muscle surface membranes. Preparative methods effect apparent chemical properties and neurotoxin binding. Biochim. Biophys. Acta 550: $59-76$

Barnett, R. E. (1970) Effect of monovalent cations on the ouabain inhibition of the sodium and potassium ion activated adenosine triphosphatase. Biochemistry 9: 4644-4648.

Bunge, R. P., and M. B. Bunge (1978) Evidence that contact with connective tissue matrix is required for normal interaction between Schwann cells and nerve fibers. J. Cell Biol. 78: 943-950.

Bunge, M. B., A. K. Williams, P. M. Wood, J. Uitto, and J. J. Jeffrey (1980) Comparison of nerve cell and nerve cell plus Schwann cell cultures, with particular emphasis on basal lamina and collagen formation. J. Cell Biol. 84: 184-202.

Bunge, M. B., A. K. Williams, and P. M. Wood (1982) Neuron-Schwann cell interaction in basal lamina formation. Dev. Biol. 92: 449-460.

Carey, D. J., C. F. Eldridge, C. J. Cornbrooks, R. Timpl, and R. P. Bunge (1983) Biosynthesis of type IV collagen by cultured rat Schwann cells. J. Cell Biol. 97: 473-479.

Cassel, D., P. M. Wood, R. P. Bunge, and L. Glasser (1982) Mitogenicity of brain axolemma membranes and soluble factors for dorsal root ganglion Schwann cells. J. Cell. Biochem. 18: 433-445.

Cornbrooks, C. J., D. J. Carey, J. A. McDonald, R. Timpl, and R. P. Bunge (1983) In vivo and in vitro observations on laminin production by Schwann cells. Proc. Natl. Acad. Sci. U. S. A. 80: 3850-3854.

DeVries, G. H., and M. Lazdunski (1982) Binding of sodium channel specific neurotoxins to rat CNS axolemma-enriched fractions. J. Biol. Chem. 257: 11684-11688.

DeVries, G. H., J. L. Salzer, and R. P. Bunge (1982) Axolemmaenriched fractions isolated from PNS and CNS are mitogenic for cultured Schwann cells. Dev. Brain Res. 3: 295-299.

DeVries, G. H., M. G. Anderson, and D. Johnson (1983a) Fractionation of isolated rat CNS myelinated axons by sucrose density gradient centrifugation in a zonal rotor. J. Neurochem. 40:1709-1717.

DeVries, G. H., L. N. Minier, and B. L. Lewis (1983b) Further studies on the mitogenic response of cultured Schwann cells to rat CNS axolemma-enriched fractions. Dev. Brain Res. 9: 87-93.

Edelman, G. M. (1983) Cell adhesion molecules. Science 219: 450-457.

Grument, M., U. Rutishauser, and G. M. Edelman (1983) Neuron-glia adhesion is inhibited by antibodies to neural determinants. Science 222: $60-62$.

Grumet, M., S. Hoffman, and G. M. Edelman (1984) Two antigenically related neuronal cell adhesion molecules of different specificities mediate neuron-neuron and neuron-glia adhesion. Proc. Natl. Acad. Sci. U. S. A. $81: 267-271$.

Hanson, G. R., and L. M. Partlow (1978) Stimulation of non-neuronal cell proliferation in vitro by mitogenic factors present in highly purified sympathetic neurons. Brain Res. 159: 195-210.

Kalderon, N. (1982) Role of the plasmin-generating system in the developing nervous tissue. I. Proteolysis as a mitogenic signal for the glial cells. J. Neurosci. Res. 8: 509-519.

Kreider, B., A. Messing, H. Doan, S. U. Kim, R. P. Lisak, and D. 
Pleasure (1981) Enrichment of Schwann cell cultures from neonatal rat sciatic nerve by differential adhesion. Brain Res. 207: 433-444.

Kreider, B. Q., J. Corey-Bloom, R. P. Lisak, H. Doan, and D. E. Pleasure (1982) Stimulation of mitosis of cultured rat Schwann cells isolated by differential adhesion. Brain Res. 237: 238-243.

Linser, P., and A. A. Moscona (1979) Induction of glutamine synthetase in embryonic neural retina: Localization in Muller fibers and dependence on cell interactions. Proc. Natl. Acad. Sci. U. S. A. 76: 6476-6480.

Linser, P., and A. A. Moscona (1983) Hormonal induction of glutamine synthetase in cultures of embryonic retina cells: Requirement for neuron-glia contact interactions. Dev. Biol. 96: 529-534.

Lowry, O. H., N. J. Rosebrough, A. L. Farr, and R. J. Randall (1951) Protein measurement with the Folin phenol reagent. J. Biol. Chem. 193: 265-275.

McCarthy, K. D., and L. M. Partlow (1976) Neuronal stimulation of $\left({ }^{3} \mathrm{H}\right)$-thymidine incorporation by primary cultures of highly purified non-neuronal cells. Brain Res. 114: 415-426.

Mithen, F. A., P. M. Wood, H. C. Agrawal, and R. P. Bunge (1983) Immunohistochemical study of myelin sheaths formed by oligodendrocytes interacting with dissociated dorsal root ganglion neurons in culture. Brain Res. 262: 63-69.

Norton, W. T., and S. Poduslo (1973) Myelination in rat brain: Method of myelin isolation. J. Neurochem. 21: 749-757.

Pleasure, D., M. Hardy, B. Kreider, J. Stern, H. Doan, S. Shuman, and S. Brown (1982) Schwann cell surface proteins and glycoproteins. I. Neurochem. 39: 486-492.

Raff, M. C., A. Hornby-Smith, and J. P. Brockes (1978a) Cyclic AMP is a mitogenic signal for cultured rat Schwann cells. Nature 273 . $672-673$.

Raff, M. C., E. Abney, J. P. Brockes, and A. Hornby-Smith (1978b) Schwann cell growth factors. Cell 15: 813-822.

Ratner, N., L. Glaser, and R. P. Bunge (1984) PC12 cells as a source of neurite-derived cell surface mitogen which stimulates Schwann cell division. J. Cell Biol. 95: 1150-1155.

Salzer, J. L., and R. P. Bunge (1980) Studies of Schwann cell proliferation. I. An analysis in tissue culture of proliferation during devel opment, Wallerian degeneration, and direct injury. J. Cell Biol. 84 $739-752$.

Salzer, J. L., A. Williams, L. Glaser, and R. P. Bunge (1980a) Studies of Schwann cell proliferation. II. Characterization of the stimulation and specificity of the response to a neurite membrane fraction. $J$. Cell Biol. 84: 753-766.

Salzer, J. L., R. P. Bunge, and L. Glaser (1980b) Studies of Schwann cell proliferation. III. Evidence for the surface localization of the neurite mitogen. J. Cell Biol. 84: 767-778.

Seil, F. J., and N. K. Blank (1981) Myelination of central nervous system axons in tissue culture by transplanted oligodendrocytes. Science 212: 1407-1408.

Sobue, G., B. Kreider, A. K. Asbury, and D. Pleasure (1983) Specific and potent mitogenic effect of axolemmal fraction on Schwann cells from rat sciatic nerves in serum-containing and defined media. Brain Res. 280: 263-275.

Sobue, G., M. Brown, S. U. Kim, and D. Pleasure (1984) Axolemma is a mitogen for human Schwann cells. Ann. Neurol. 15: 449-452.

Wartiovaara, J., E. Linder, E. Rouslahti, and A. Vaheri (1974) Distribution of fibroblast surface antigen: Association with fibrillar structures of normal cells and loss upon viral transformation. J. Exp. Med. 140: 1522-1533.

Weinberg, H. J., and P. S. Spencer (1976) Studies on the control of myelinogenesis. II. Evidence for neuronal regulation of myelin production. Brain Res. 113: 363-378.

Wharton, D. C., and A. Tzagoloff (1967) Cytochrome oxidase from beef heart mitochondria. Methods Enzymol. 10:245-250.

MeWood, P. M., and R. P. Bunge (1975) Evidence that sensory axons are mitogenic for Schwann cells. Nature 256: 662-664.

Wood, P., E. Okada, and R. Bunge (1980) The use of networks of dissociated rat dorsal root ganglion neurons to induce myelination by oligodendrocytes in culture. Brain Res. 196: 247-252. 